\title{
Yeast feeds debate on prolonging life
}

'Eating less helps you live longer' has for decades been the message from researchers of ageing. So experts are not sure what to make of a study in flies that suggests it could be what you eat, not how much you eat, that really counts.

The idea that restricting calories prolongs lifespan was first reported in 1935, following studies in rats. The observation has since been supported by studies in species ranging from worms to dogs. The source of the calories is generally considered irrelevant.

Now a research team from University College London has extended the lifespan of Drosophila flies by reducing the amount of yeast (a source of protein and fat) or sugar in their diets. The team, led by Linda Partridge, observed a much more dramatic effect with yeast than with sugar, even though the overall change in calorie content was the same. The results are published online in PLoS Biology this week (W. Mair et al. 3, 223; 2005).

The finding hints that reducing protein and fat might be the key to living longer, rather than cutting down on the total number of calories. But many researchers are sceptical of drawing any broad conclusions. "We already saw what a disaster it was in the 1990s with fad diets that lowered fats and increased carbs," says Leonard Guarente, a molecular biologist at the Massachusetts Institute of Technology in Cambridge. "That's when people really got fat."

\author{
IMAGE \\ UNAVAILABLE \\ FOR COPYRIGHT \\ REASONS
}

Roll on the years: reducing calorie intake may help you live longer, but does it matter what you eat?

He thinks the results may simply reflect a peculiarity of flies. "You need to know how well flies metabolize glucose compared with yeast," he says.

Sige Zou, a fly geneticist at the National Institute on Aging in Baltimore, adds that other components in the yeast might also be having an effect. "Yeast are made up of a lot of ingredients," he says. He would like to see the experiment repeated using pure protein or fat extracts.

Partridge's study shows how tricky it can be to pin down such effects, agrees Richard Weindruch, a gerontologist at the University of Wisconsin at Madison. "This solidifies my concerns about the nuances and difficulties of conducting studies of caloric restriction in some model organisms."

But researchers are sure, at least, that restricting calories does prolong lifespan, even if they do not know how. "The name of the game is not to take in more energy than you need," says Guarente.

How many calories would humans need to cut to gain years, or even decades? "Based on our mouse data, I'd guess a minimum of $20 \%$ from a predetermined baseline, for a person who is not obese," says Weindruch.

Weindruch is currently evaluating dietrestricted rhesus monkeys, in a study that started more than a decade ago. "The monkeys are now middle-aged and it is clear the diet is doing them good," says Weindruch. They are protected from type II diabetes, a common ailment in ageing monkeys, and seem to have healthier hearts. "I look forward to reporting the outcome," he says, "assuming the monkeys don't outlive me!"

Carina Dennis

\section{Drug giants fail to name compounds in trial database}

\section{WASHINGTON DC}

An international group of medical editors is challenging several leading pharmaceutical companies, saying that their reporting of clinical trials is deliberately incomplete.

The International Committee of Medical Journal Editors made their complaint in an editorial in The New England Journal of Medicine, published online on 23 May. They argue that leading pharmaceutical companies are obeying the letter but not the spirit of a 1997 law that requires the public registration of ongoing trials involving serious or life-threatening illnesses.

The government-maintained registry, www.clinicaltrials.gov, is intended to help patients find information about clinical trials. But the editors say that drug firms are inserting a "meaningless phrase" instead of the names of drugs, so patients aren't getting the full picture, including any negative data.

The New England journal's editor-inchief, Jeffrey Drazen, says that Merck, GlaxoSmithKline (GSK) and Pfizer in particular "didn't meet the sniff test" in a review conducted early this month by Deborah Zarin, the database's director. Zarin found that specific drug names were missing in scores of trials, which used the phrase "investigational drug" to describe their products. Drugs weren't named in 36\% of 75 Pfizer studies reviewed, in 53\% of 55 GSK trials, and in $90 \%$ of 132 Merck trials.

Drazen argues that patients deserve more. "It's not right," he says.

The drug companies insist that they are trying to make the reporting of results as transparent as possible. They claim they are complying with the law, which does not explicitly require companies to name drugs, but asks them to describe the "intervention" being used. "We think we've made big strides in improving the transparency of clinical data. And we will continue to do so," says GSK spokesman Rick Koenig.

Pfizer's spokeswoman Betsy Raymond says her company withholds the names of certain drugs for competitive reasons. Merck did not return a call seeking comment.

The editors' committee wants to see trials being publicly registered in a meaningful way, partly so that negative results about particular drugs can be accessed. They have defined a list of minimum criteria that companies must provide. And this summer, the editors will start refusing to publish trials that do not register this information. The editorial "is a message that we are paying close attention", says Drazen.

Meredith Wadman 